\title{
Ethno-botanical survey of Palamalai Hills, Mettur Taluk, Eastern Ghats, India
}

\author{
L. Thamaraiselvi', E. G. Wesely', M.D. Nazneen Bobby², Vinod Kumar Nathan 3* \\ 'Department of Botany, A.A. Government Arts College, Namakkal 637 002, India, ${ }^{2}$ Vignan university, VFSTR, \\ Vadlamudi post, Guntur 522 213, Andhra Pradesh, India, ${ }^{3}$ National Institute of Oceanography-CSIR, Regional Centre, \\ Cochin 682 018, Kerala, India
}

Received: August 21, 2018 Accepted: October 12, 2018 Published: November 16, 2018

\section{*Corresponding Author:}

Vinod Kumar Nathan, National Institute of Oceanography-CSIR, Regional Centre, Cochin 682

018, Kerala, India

Email: nvkibt@gmail.com

\section{ABSTRACT}

Ethnobotanical survey of Palamali hills, a part of Eastern Ghats was carried out for reporting the preliminary traditional knowledge from the inhabitant tribal community. Through the survey, we identified 18 plants which possess medicinal properties. This report is a preliminary checklist and will be helpful for people in identifying potential bioresource and initiating conservatory measures. The present investigation showed that, the tribes of Palamalai Hills of Mettur Taluk, Eastern Ghats, India possess rich knowledge of the medicinal plants and their utilization. There is a need of scientific awareness for prevention of most of the diseases and the cultivation of above medicinal plants for both the utilization , and the conservation of natural resources.

KEYWORDS: Ethnobotany, traditional knowledge, medicinal plants

\section{INTRODUCTION}

India is one of the top countries of the world in plant species richness and fourth among the Asian countries. We are still dependent on the ethno-medical practices because of readily availability of medicinal plants and their less expense compared to other medicinal systems. However, the traditional knowledge on the usage of most of the plants are unknown to us and it is only known to the tribal inhabitants. Hence, understanding the traditional knowledge through tribal participatory research is essential to carry on the knowledge to future generations. This paper discusses on the traditional knowledge of tribes and villagers of Palamalai Hills, Salem District, and Tamil Nadu through an ethnobotanical survey.

The Palamali Hills is situated in the Salem district of Tamil Nadu, lies between $11^{\circ} 14.46^{\prime}$ and $12^{\circ} 53.30^{\prime}$ North latitude and between

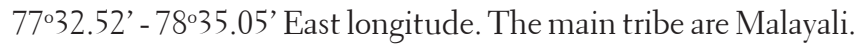
Only few studies are existing on the traditional knowledge of these area $[1,2]$. Still there are many unexplored regions and communities within the Palamali Hills and this investigation was undertaken in manner to ascertain the detailed knowledge on ethno-medicinal plants used by tribal (Malayali) and rural people. Documenting of these domestic knowledge through ethnobotanical studies will be an asset for future.

\section{MATERIALS AND METHODS}

\section{Study Area}

Palamalai Hills is an under explored and biodiversity rich region of Eastern Ghats in southern India. Which is exactly situated at Mettur Taluk belongs to Salem district of Tamil Nadu, India. It has the height of latitude about 11.73 whereas longitude about 77.74 and 300 odd tribals of Palamalai hills present at the $30 \mathrm{~km}$ upper from the down area. It is located $4000 \mathrm{~m}$ upper from the mean sea level (MSL) and more over the climate of the district is whole dry except North East monsoon seasons. This may be divided into four seasons such as cold season, hot season, southwest season and post monsoon season. For generations, agriculture and cattle rearing have been the only source of income for their family.

\section{Method}

Ethnopharmacological field survey and the identification of Ethnobotanical habitat were made to tribal communities of Palamalai Hills during the period of $11^{\text {th }}$ August 2016 to $21^{\text {St }}$ January 2017. Information was gathered on medicinal plants from the local tribes, herbalist and village people around the Palamalai Hills through personal communication, questionnaire, and discussion among the elder people of surrounding villages. In order to know the phenology of the plants an intensive and extensive 
field survey of Palamalai hills, Mettur taluk, Salem district were made. The data were collected through repeated field visits and the careful interaction with the rural people and traditional practitioners in their local language (Tamil). The collected plant specimens were identified taxonomically with the help of BSI (botanical Survey of India) located at Coimbatore District, Tamil Nadu, which is certified in the date of $3^{\text {rd }}$ November 2016.

\section{RESULTS AND DISCUSSION}

The present study showed that some plants of Palamalai Hills, Salem district used by tribals for treating various disorders. A total of 18 species of plants were identified and representatives from Euphorbiaceace were dominant. All the 18 species have medicinal uses. Some of the common plants identified were Cardiospermum helicacabum, Datura metel, Aerva lanata, Acacia catechu, Passiflora foetida, Solanum violaceum and Acalypha diversifolia. They are from various plant groups of vine, shrubby herb, woody, tree, climber and shrub etc., The details of the collected plants including botanical name, family name, their medicinal uses were described below.

\section{Cardiospermum helicacabum, Linn (Sapindaceae)}

Annual or perennial climbing plant, generally found as a weeds and eaten as vegetables to cure joint pains. The juice from this plant is often used for treatment of ear ache. A decoction of root is given for bleeding piles [3]. The tender, young shoots are used as a vegetable, fodder, diuretic, stomachic, and to reduce tough cysts. Extract showed analgesic, anti-inflammatory and vasodepressant activities in earlier reports [4]. Leaves in water preparations used for hair cleaning and removal of dandruff.

\section{Datura metel L. (Solanaceae)}

A shrub-like perennial herb grows in the wild in all the warmer parts of the world, such as India. Fruit powder mixed with coconut oil is applied on the skin of cheap for curing skin disorder. It is used to cure toxic effects of drunkenness, hallucinations and visions [5]. The leaf juice mixed with black pepper to cure cough asthma and chronic ulcers. Leaf paste or oil is used for external application to relieve pain, inflammation, itching and infested wounds and to relieve fever.

\section{Aerva lanata (L.) Juss. (Amaranthaceae)}

Annual herb with a branching, somewhat woody root system. Antipathogenic, diuretic, demulcent which helps in relieving pain and inflammation. Anthelmintic and astringent activities were reported. Plant is used for diarrhea and hemorrhages. Antioxidant property was reported from this plant parts. Used for increasing memory power, headache, abdomen and digestion
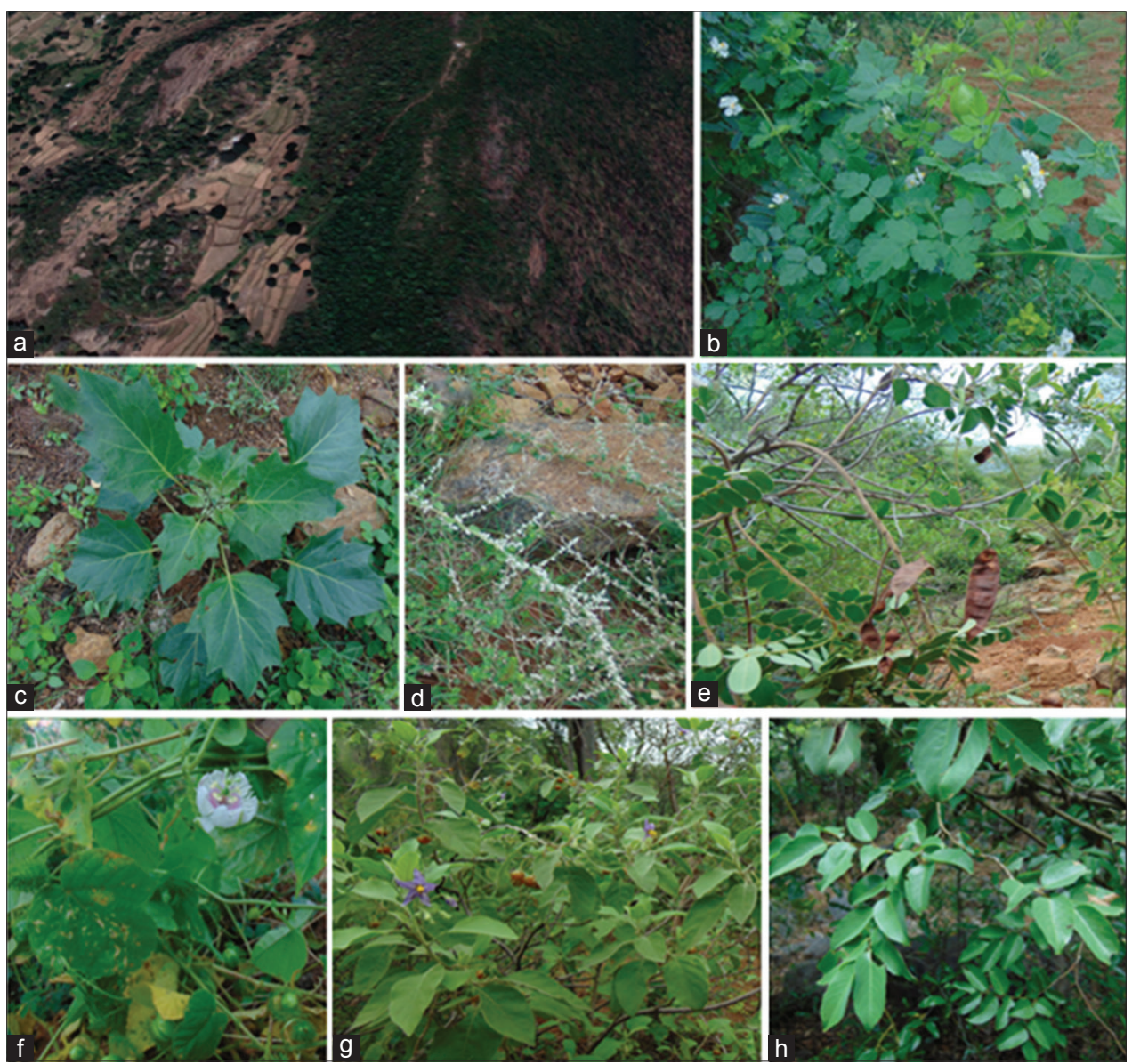

Figure 1: Study site map and its prominent flora identified b) Cardiospermum Halicacabum. L c) Datura metel L. d) Aerva lanata (L.) e) Acacia catechu (L. f) willd. f) Passiflora foetida L. g) Solanum violaceum Ortega and h) Acalypha diversifolia Jacq 
problems, neck and back pain, fever and also regulates body metabolism [6].

\section{Acacia catechu (L. f) willd. (Mimosaceae)}

This plant was used majorly for the purpose of dyeing and tanning. Liver sluggishness and swelling are some of the liver ailments that can be relieved by using the extract of Acacia catechu. This therapeutic plant helps in clotting blood in case of excessive bleeding. Acacia catechu extract is used for the purpose of gargling to relieve the problem of gingivitis. It is also used for the management of life threatening diseases like Leukaemia Asthma, Bronchitis and cough and also relieves dysentery, diarrhoea and the problem of stomatitis [7].

\section{Passiflora foetida L.(Passifloraceae)}

Passiflora foetida has been mentioned as a toxic plant by farmers from North-eastern Brazil. The plant has been used for skin problems with inflammation and an infusion made from it cures sore throat. Leaves used in giddiness and headache and for curing asthma. Fruits are emetic [8].

\section{Solanum violaceum Ortega. (Solanaceae)}

There are many reported uses for this plant like digestive, carminative, cardiac tonic, expectorant and aphrodisiac, nasal ulcer, and to stop vomiting.

\section{Acalypha diversifolia Muell. Arg. (Euphorbiaceae)}

Used to cure headache, swelling and colds. used as painkillers, for naso-pharyngeal infections, as antibiotic, bacteriostatic, and fungistatic [9].

\section{Strychnos nux-vomica L. (Loganiaceae)}

Crude extract is used in the treatment of anemia, lumbago, asthma, bronchitis, constipation, diabetes, malarial fever, skin disease, paralysis, muscle weakness, and appetite loss. Plant is used traditionally for treating diabetes [10].

\section{Dendrophthoe falcata (L. f.) Ettingsh (Loranthaceae)}

The plant possesses wound healing, antimicrobial, hepatoprotective, antidiabetic, anticancer, antinociceptive, anthelmintic, antioxidant and antiseptic properties. There are properties against pulmonary tuberculosis, asthma, menstrual disorders, constipation, insanity, diarrhoea, dysentery, arthritis, leucorrhoea, rheumatism, skin diseases, impotency, wound swelling, paralysis, ulcers, haemorrhage, miscarriage, kidney and gall bladder stone [11].

\section{Wrightia tinctoria R. Br. (Appocynaceae)}

This plant is used against toothache, fever, stomach ache, skin diseases and has anti-inflammatory and anti-dandruff properties [12].

\section{Neolitsea cassia (L.) Kosterm. (Lauraceae)}

The bark and leaves are used for treatment of fractures.

\section{Cocculus hrsutus s (L.) Diels (Menispermaceae)}

Root used to cure burning sensation, clean urinary system, antipyretic, tonic, lessens thirsty, good for fractures, and useful in tubercular glands related problems [13].

\section{Cadaba indica Lam (Capparidaceae)}

The plant is used as insectidices. Extract is used for treating skin diseases, uterine obstruction, anthelmentic, purgative, deobstruent, emmenagogue and antisyphillictic, eczema, swelling, constipation and boils; its leaf juice is used as eye drops [14].

\section{Grewia tiliaefolia Vahl (Tiliaceae)}

The leaves have antibacterial action and can be used as fodder [15].

\section{Acalypha fruticose Forssk. (Euphorbiaceae)}

Traditional uses like treatment of stomachache, dyspepsia, venom antidote, rheumatism and dermatitis [16, 17].

\section{Diospyros ferrea (Willd) Bakh. (Ebenaceae)}

The extract is used to cure insomnia and hiccough, as antihypertensive, astringents and bactericidal [18].

\section{Glochidion heyneanum (Wight \& Arn.) Wight. (Phyllanthaceae)}

The plant is used as anti-hypertensive, vermicide, vermifuge, sedative etc. The plant extract possesses immunomodulatory property [19].

\section{Bridelia retusa Spreng. (Euphorbiaceae)}

The bark of plant is used by tribal people in treatment of rheumatism, antiviral, in snake bite and to produce sterility [20].

\section{CONCLUSION}

Literature shows many traditional as well as ethnomedicinal uses for these plants in Salem District. But this is the first attempt therapeutic plants record on Palamalai hills, Salem District, India. Our results showed 18 species of plants are used by the tribal people of Palamalai hills for the treatment of various diseases such as diarehea, skin disorder, drunkenness, hallucinations, vision problems, Cough asthma, chronic ulcers, urethral problems, lithiasis, gonorrhoea, body pain, inflammation, excessive bleeding, catarrh, colic, flatulence, worms, dysuria, toothache, fever, 
vomiting, pruritus, leucoderma, etc. The present investigation showed that, the tribes of Palamalai hills possess rich knowledge of the medicinal plants and their utilization. There is a need of scientific awareness for prevention of most of the diseases and the cultivation of above medicinal plants for both the utilization and the conservation of natural resources.

\section{ACKNOWLEDGEMENT}

Authors acknowledge the Department of Botany, AA Government Arts College, Namakkal for their support. Special gratitude to the tribals and villagers who cooperated in the survey.

\section{REFERENCES}

1. Alagesaboopathi C. Ethnomedicinal plants used for the treatment of snake bites by Malayali tribal's and rural people in Salem district, Tamilnadu, India. Int J Biosci. 2013; 3:42-53.

2. Silambarasan R, Ayyanar M. An ethnobotanical study of medicinal plants in Palamalai region of Eastern Ghats, India. Journal of ethnopharmacology. 2015; 172:162-78.

3. Peiris LD, Dhanushka MA, Jayathilake TA. Evaluation of aqueous leaf extract of Cardiospermum halicacabum (L.) on fertility of male rats. BioMed research international. 2015; 2015.

4. Zalke AS, Duraiswamy B, Gandagule UB, Singh N. Pharmacognostical evaluation of Cardiospermum halicacabum Linn. leaf and stem. Ancient science of life. 2013; 33(1):15.

5. Parveen A. Medicinal values of Datura: A synoptic review. International Journal of Green Pharmacy (IJGP). 2016;10(2)

6. Goyal M, Pareek A, Nagori BP, Sasmal D. Aerva lanata: A review on phytochemistry and pharmacological aspects. Pharmacognosy reviews. 2011; 5(10):195.

7. Saha MR, Dey P, Begum S, De B, Chaudhuri TK, De Sarker D, Das AP, Sen A. Effect of Acacia catechu (Lf) Willd. on oxidative stress with possible implications in alleviating selected cognitive disorders. PloS one. 2016;11(3): e0150574.

8. Sasikala V, Saravanan S, Parimelazhagan T. Analgesic and antiinflammatory activities of Passiflora foetida L. Asian Pacific journal of tropical medicine. 2011;4(8):600-3.

9. Burkill HM. The useful plants of west tropical Africa. Volume 2: Families El. Royal Botanic Gardens; 1994; p. 127.

10. Gruenwald J. $2^{\text {nd }}$ ed. Montvale: Thomson Healthcare; PDR for herbal medicines: 2000; p. 548.

11. Rothe SP, Maheshwari AA. Addition to the hosts of partial stem parasite Dendrophthoe falcata (L. f.) Ettingsh from east melghat forest. World Journal of Pharmacy and Pharmaceutical Sciences. 2017; 6(8): 2046-2051

12. Srivastava R. A review on phytochemical, pharmacological, and pharmacognostical profile of Wrightia tinctoria: Adulterant of kurchi. Pharmacognosy reviews. 2014; 8(15):36

13. Marya H, Bothara B. Ethnopharmacological properties of Cocculus hirsutus (L.) Diels-a review. International Journal of Pharmaceutical Sciences Review and Research. 2011; 7(1):108-12.

14. Tamizhazhagan V. In silico docking analysis of Delonix elata leaf extracts to inhibit cervical cancer hpv16 in albino wistar rat. Innoriginal: International Journal of Sciences. 2018; 26:21-4.

15. Kumar VR, Venkatachalam VV. Physicochemical evaluation and phytochemical investigation of the leaves of Grewia tiliaefolia Vahl. Der Pharmacia Lettre. 2016; 8 (20):52-56.

16. Senthilkumar M, Gurumoorthi P, Janardhanan K. Some medicinal plants used by Irular, the tribal people of Marudhamalai hills, Coimbatore, Tamil Nadu. 2006; Natural Product Radiance. 2006; 5(5): 382-388.

17. Mothana RA, Abdo SA, Hasson S, Althawab F, Alaghbari SA, Lindequist U. Antimicrobial, antioxidant and cytotoxic activities and phytochemical screening of some yemeni medicinal plants. Evidencebased Complementary and alternative medicine. 2010;7(3):323-30.

18. Vijayalakshmi R, Ravindhran R. Preliminary comparative phytochemical screening of root extracts of Diospyrus ferrea (Wild.) Bakh and Aerva lanata (L.) Juss. Ex Schultes. Asian J Plant Sci Res. 2012; 2(5):581-7.

19. Chaitanya RS, Sandhya S, David B, Vinod KR, Murali S. HRBC membrane stabilizing property of roor, stem and leaf of Glochidion velutinum. Int J Res Pharmaceut Biomed Sci. 2011; 2(1):256-9.

20. Ngueyem TA, Brusotti G, Caccialanza G, Finzi PV. The genus Bridelia: a phytochemical and ethnopharmacological review. Journal of Ethnopharmacology. 2009;124(3):339-49. 